\title{
Synthesis, X-ray Structural Characterization, and DFT Calculations of Mononuclear Nickel(II) Complexes Containing Diamine and Methacrylate Ligands
}

\author{
Rasoul Vafazadeh, ${ }^{1,}{ }^{*}$ Mansoor Namazian, ${ }^{1}$ Behnoosh Shahpoori-Arani, ${ }^{1}$ \\ Anthony C. Willis ${ }^{2}$ and Paul D. Carr \\ ${ }^{1}$ Department of Chemistry, Faculty of Science, Yazd University, Yazd, Iran. \\ ${ }^{2}$ Research School of Chemistry, Australian National University, Canberra, ACT 2601, Australia. \\ *Corresponding author: E-mail: rvafazadeh@yazd.ac.ir
}

Received: $14-12-2017$

\begin{abstract}
The mononuclear $\mathrm{Ni}(\mathrm{II})$ complexes $\left[\mathrm{Ni}(\mathrm{en})_{2}\left(\mathrm{H}_{2} \mathrm{O}\right)_{2}\right](\mathrm{MAA})_{2}(\mathbf{1})$ and $\left[\mathrm{Ni}(\mathrm{pn})_{2}(\mathrm{MAA})_{2}\right](2)$, where MAA, en and pn are methacrylate, ethylendiamine and 1,3-propylendiamine, respectively, have been synthesized and characterized by elemental analysis, FT-IR and UV-Vis spectroskopy. Structures of the complexes have been determined by single-crystal $\mathrm{X}$-ray diffraction analyses. In the nickel(II) complexes $\mathbf{1}$ and $\mathbf{2}$ nickel(II) ion is six-coordinate and has a distorted octahedral geometry. $\mathrm{Ni}(\mathrm{II})$ is bonded to four nitrogen atoms of the two diamines and additionally to two oxygen atoms of aqua ligand in $\mathbf{1}$, and two oxygen atoms of methacrylate ligands in $\mathbf{2}$. The theoretical geometries of the studied compounds have been calculated by means of density functional theory (DFT) at the B3LYP/6-311+G(d,p)/LanL2DZ level and considering effective core potential (ECP). The comparison of the results indicates that the employed DFT method yields good agreement with experimental data.
\end{abstract}

Keyword: Nickel(II) complex; mononuclear; methacrylate; diamine; DFT

\section{Introduction}

Transition metal complexes containing poly-dentate amine ligands the most widely used in coordination chemistry. ${ }^{1-5}$ There have been numerous of investigation on polydentate amines. These ligands, and in particular diamines such as ethylene diamine (en) and 1,3-propane diamine (pn) find great utility due to ease synthesis and the ability to form stable complexes with first-row transition metal ions. ${ }^{5-9}$ On the other hand, the complexes with organic, inorganic carboxylates and their derivatives are widely used in coordination chemistry. The carboxylates in the complexes exhibit various possible bonding modes, mono- and bidentate by forming chelation or bridges in coordinating to the transition metal. The coordination mode of the carboxylate ligands depends on metal ion and other ligands employed in the synthesis of the complexes. ${ }^{10-15}$

In our previous work, we reported the synthesis, spectroscopic characterization, structural aspects and density functional theory (DFT) calculations for two $\mathrm{Cu}(\mathrm{II})$ complexes containing diamine, acetate, and methacrylate ligands. ${ }^{15}$ In order to investigate the effect of the metal on the structural complexes with these ligands, we

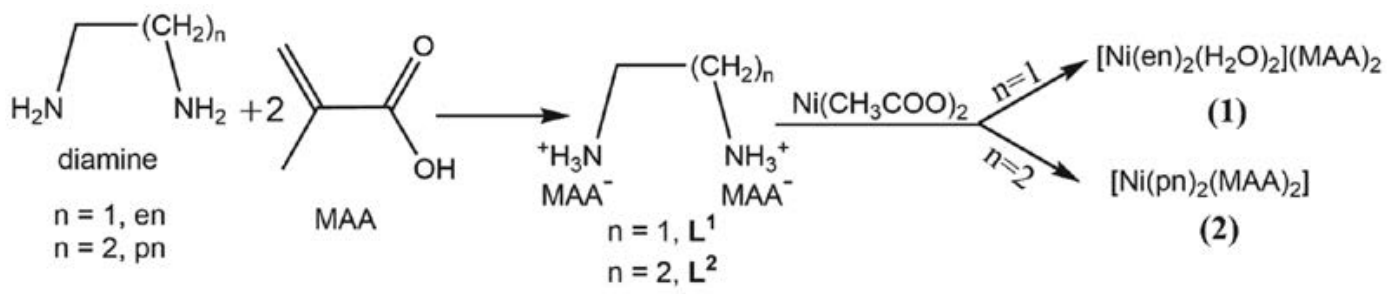

Scheme 1. Synthesis of the complexes $\mathbf{1}$ and $\mathbf{2}$ 
carried out the synthesis of two Ni(II) complexes by reaction of diaminum-methacrylic acid salt (diamines are ethylendiamine and 1,3-propylendiamine) with $\mathrm{Ni}$ (II) acetate (Scheme 1). The structures of the complexes have been determined by single-crystal X-ray diffraction analyses and calculated by density functional theory.

\section{Experimental}

\section{1. Starting Materials and Physical Measurements}

All chemicals were of analytical reagent grade and were used without further purification. Infrared spectra were taken with an Equinox 55 Bruker FT-IR spectrometer using $\mathrm{KBr}$ pellets in the $400-4000 \mathrm{~cm}^{-1}$ range. Absorption spectra were determined in the solvent of dimethylformamide (DMF) using GBC UV-Visible Cintra 101 spectrophotometer with $1 \mathrm{~cm}$ quartz, in the range of 200-800 nm. Elemental analyses (C, H, N) were performed by using a CHNS-O 2400II PERKIN-ELMER elemental analyzer.

\section{2. X-Ray Crystallography}

Diffraction images of $\mathbf{1}$ and $\mathbf{2}$ were measured at 150 $\mathrm{K}$ on Agilent Xcalibur and SuperNova diffractometers using $\mathrm{Cu} \mathrm{Ka}(\lambda=1.54180 \AA)$ and $\mathrm{Mo} \mathrm{Ka}(\lambda=0.71073 \AA)$ radiation, respectively. Data were extracted using the

Table 1. Crystallographic data and structural refinement for complexes $\mathbf{1}$ and $\mathbf{2}$

\begin{tabular}{lll}
\hline Compound & $\mathbf{1}$ & $\mathbf{2}$ \\
\hline Empirical formula & $\mathrm{C}_{12} \mathrm{H}_{30} \mathrm{~N}_{4} \mathrm{NiO}_{6}$ & $\mathrm{C}_{14} \mathrm{H}_{30} \mathrm{~N}_{4} \mathrm{NiO}_{4}$ \\
Formula weight & 385.10 & 377.13 \\
Crystal system & Monoclinic & Monoclinic \\
Space group & $\mathrm{C} 2 / \mathrm{c}$ & $\mathrm{P} 2{ }_{1} / \mathrm{c}$ \\
Temperature $(\mathrm{K})$ & 150 & 150 \\
$a / \AA$ & $24.4016(10)$ & $10.0738(5)$ \\
$b / \AA$ & $6.9977(3)$ & $8.3205(3)$ \\
$c / \AA$ & $10.7021(6)$ & $11.1221(6)$ \\
$\alpha /{ }^{\circ}$ & 90 & 90 \\
$\beta / /^{\circ}$ & $93.316(4)$ & $103.659(3)$ \\
$\gamma /{ }^{\circ}$ & 90 & 90 \\
$V / \AA^{3}$ & $697.29(9)$ & $1610.89(6)$ \\
$Z$ & 4 & 2 \\
$F(000)$ & 824 & 404 \\
$d_{\text {calc }}(\mathrm{g}$ cm & -3 \\
$\left.\mu(\mathrm{mm})^{-1}\right)$ & 1.402 & 1.383 \\
Measured reflections & 1.84 & 1.10 \\
Independent reflectionss & 9955 & 10433 \\
Observed reflections & 1803 & 2280 \\
$R_{\text {int }}$ & 1710 & 1868 \\
$R\left[F^{2}>2 \sigma\left(F^{2}\right)\right]$ & 0.036 & 0.044 \\
$w R\left(F^{2}\right)($ all data) & 0.054 & 0.043 \\
\hline
\end{tabular}

CrysAlis PRO package. ${ }^{16}$ The structures were solved by direct methods with the use of SIR92. ${ }^{17}$ The structures were refined on $F^{2}$ by full matrix last-squares techniques using the CRYSTALS program package. ${ }^{18}$ Atomic coordinates, bond lengths, and angles and displacement parameters have been deposited at the Cambridge Crystallographic Data Centre. Crystallographic data and refinement details for the complexes are given in Table 1. Details of the refinement procedures for the structures are given in the Supplementary Information.

\subsection{Theoretical Calculations}

All computations were performed by means of standard DFT method using the Gaussian09 (G09) program package. ${ }^{19,20}$ The geometries of the studied complexes have been optimized at the B3LYP level of the theory. ${ }^{21}$ The basis set of 6-31G(2df,p) was used for the $\mathrm{C}, \mathrm{H}, \mathrm{N}$, and $\mathrm{O}$ atoms as recommended by Curtiss and his co-workers, ${ }^{22}$ while the basis set of LanL2DZ was employed for Ni atom considering the size of complexes and hardware limitations ${ }^{23-25}$ Special care was taken to select the (global) minimum energy conformation via systematic conformational searching at this level. The nature of each stationary point was established by frequency calculations at the same level of B3LYP/6-31G(2df,p)/LanL2DZ. The geometry optimizations have been completed in the absence of solvent molecules and other impurities, and the optimized structures were compared with the crystalline structures. Charges on atoms have been calculated using Natural Bond Orbital (NBO) theory at the higher level of B3LY$\mathrm{P} / 6-311+\mathrm{G}(2 \mathrm{df}, \mathrm{p}) /$ LanL2TZf. ${ }^{26,27}$

\section{4. Syntheses of Compounds $L^{1}$ and $L^{2}$}

The compounds $\mathbf{L}^{1}$ and $\mathbf{L}^{2}$ were prepared as previously reported elsewhere by us by reaction between two equivalents of methacrylic acid $(20 \mathrm{mmol}, 1.70 \mathrm{~mL})$ and one equivalent of related diamine, 1,2-ethylendiamine (10 $\mathrm{mmol}, 0.67 \mathrm{~mL})$ and 1,3-propandiamine $(10 \mathrm{mmol}, 0.84$ $\mathrm{mL})$ in methanol $(40 \mathrm{~mL})$, respectively. ${ }^{15}$ The resulting bright yellow solution was heated to reflux for two hours. After two days, the solid yellow powder obtained was filtered, washed with acetone and acetonitrile, and dried in air.

\section{5. Synthesis of Nickel(II) Complexes}

$\mathrm{Ni}\left(\mathrm{CH}_{3} \mathrm{COO}\right)_{2} \cdot 4 \mathrm{H}_{2} \mathrm{O}(2.00 \mathrm{mmol}, 0.496 \mathrm{~g})$ was slowly added to an ethanol solution $(40 \mathrm{~mL})$ of the corresponding compound $\left(\mathbf{L}^{1}, 2.00 \mathrm{mmol}, 0.464 \mathrm{~g} ; \mathbf{L}^{2}, 2.00\right.$ $\mathrm{mmol}, 0.492 \mathrm{~g}$ ) and the resulting solution was stirred for two hours at room temperature. Two days upon evaporation of the solvents, a blue-green oil formed. The oil form obtained was re-suspended in ether and stirred at room temperature until a precipitate formed. The solid product 
was recrystallized from suitable solvents according to the following procedures:

$\left[\mathrm{Ni}(\mathrm{en})_{2}\left(\mathrm{H}_{2} \mathrm{O}\right)_{2}\right](\mathrm{MAA})_{2}(\mathbf{1})$

Yield: $0.36 \mathrm{~g}(47 \%)$. The light violet solid product was recrystallized from dichloromethane/toluene $(1: 1 \mathrm{v} / \mathrm{v})$. The light violet crystals were filtered and dried in air. Anal. Calc. for $\mathrm{C}_{12} \mathrm{H}_{30} \mathrm{~N}_{4} \mathrm{NiO}_{6}$ (385.09): C, 37.43; $\mathrm{H}, 7.85 ; \mathrm{N}$, $14.55 \%$. Found: C, 37.62; H, 7. 91; N, $14.39 \%$. IR ( $\mathrm{KBr}$, $\left.\mathrm{cm}^{-1}\right): 3276,3192,1628,1547$ and 1450. Electronic spectra for $\mathrm{CH}_{3} \mathrm{OH}: \lambda_{\max }(\log \varepsilon) 225 \mathrm{~nm}$ (2.93), $284 \mathrm{~nm}$ (2.46), 370 $\mathrm{nm}(2.26), 631 \mathrm{~nm}(0.93)$ and $1009 \mathrm{~nm}(0.93)$.

[Ni(pn $\left.)_{2}(\mathrm{MAA})_{2}\right](2)$

Yield: $0.50 \mathrm{~g}(66 \%)$. The blue-green solid product was recrystallized from dichloromethane/n-hexane/toluene $(3: 1: 2 \mathrm{v} / \mathrm{v})$. Blue crystals were filtered and dried in air. Anal. Calc. for $\mathrm{C}_{14} \mathrm{H}_{30} \mathrm{~N}_{4} \mathrm{NiO}_{4}$ (377.11): C, 44.59; $\mathrm{H}, 8.02$; $\mathrm{N}, 14.86 \%$. Found: C, 44.82; H, 8.18; N, $14.66 \%$. IR (KBr, $\mathrm{cm}^{-1}$ ): 3290, 3176, 1632, 1546 and 1451. Electronic spectra for $\mathrm{CH}_{3} \mathrm{OH}$ : $\lambda_{\max }(\log \varepsilon) 226 \mathrm{~nm}(4.60), 284 \mathrm{~nm}$ (3.65), 377 $\mathrm{nm}(3.40), 630 \mathrm{~nm}(0.71)$ and $1041 \mathrm{~nm}(0.46)$.

\section{Results and Discussion}

\section{1. Syntheses and Characterization of the Complexes}

The diaminum-methacrylic acid salt ligands were obtained by reaction of related diamine (ethylendiamine, en, and 1,3-propylendiamine, pn) and methacrylic acid in methanol under reflux. The reaction of nickel(II) acetate with $\mathbf{L}^{1}$ and $\mathbf{L}^{2}$ leads to the formation of mononuclear complexes 1 and 2, while in the reaction of copper(II) acetate with these ligands dinuclear copper complexes were formed.

The most significant IR bands for ligands and complexes are given in the experimental section. In the IR spectra of the compounds $\mathbf{L}^{1}$ and $\mathbf{L}^{2}$ two strong bands at 1650 and $1455 \mathrm{~cm}^{-1}$ (for $\mathbf{L}^{1}$ ) and 1646 and $1455 \mathrm{~cm}^{-1}$ (for $\left.\mathbf{L}^{2}\right)$ corresponding to stretching frequencies of the carboxylate group: asymmetric $v_{\text {asym }}\left(\mathrm{COO}^{-}\right)$and symmetric $v_{\text {sym }}\left(\mathrm{COO}^{-}\right)$, respectively.

In IR spectra of $\mathbf{1},\left[\mathrm{Ni}(\mathrm{en})_{2}\left(\mathrm{H}_{2} \mathrm{O}\right)_{2}\right](\mathrm{MAA})_{2}$, the appearance of two bands at 1628 and $1450 \mathrm{~cm}^{-1}$ due to asymmetric $v_{\text {asym }}\left(\mathrm{COO}^{-}\right)$and symmetric $v_{\text {sym }}\left(\mathrm{COO}^{-}\right)$, respectively, reveal the uncoordinated methacrylate ions. In contrast, complex $2,\left[\mathrm{Ni}(\mathrm{pn})_{2}(\mathrm{MAA})_{2}\right]$, shows two strong bands at 1632 and $1381 \mathrm{~cm}^{-1}$ corresponding to stretching frequencies of the carboxylate group: asymmetric $v_{\text {asym }}\left(\mathrm{COO}^{-}\right)$and symmetric $v_{\text {sym }}\left(\mathrm{COO}^{-}\right)$, respectively. The difference between asymmetric and symmetric frequencies $\left(\Delta\left[v_{\text {asym }}\left(\mathrm{COO}^{-}\right)-v_{\text {sym }}\left(\mathrm{COO}^{-}\right)\right]>200 \mathrm{~cm}^{-1}\right)$ indicates a monodentate coordination mode for the methacrylate ion (see the description of X-ray crystal structures section). ${ }^{10,12,28,29}$

The absorption spectra of the compounds $\mathbf{L}^{1}$ and $\mathbf{L}^{2}$ in methanol solution show band $n-\pi^{*}$ transitions at 226 and $216 \mathrm{~nm}$, respectively. Electronic spectra of 1 and 2 show broad bands at 1009 and $631 \mathrm{~nm}$ (for 1) 1041 and $630 \mathrm{~nm}$ (for 2), respectively. These spectral features are consistent with six-coordinate octahedral geometry for $\mathrm{Ni}(\mathrm{II})$. These bands arise from spin-allowed $\mathrm{d}-\mathrm{d}$ transitions of the nickel(II) ion in a distorted octahedral environment where two maxima observed in the visible region result from ${ }^{3} \mathrm{~A}_{2 \mathrm{~g}} \rightarrow{ }^{3} \mathrm{~T}_{1 \mathrm{~g}}$ and ${ }^{3} \mathrm{~A}_{2 \mathrm{~g}} \rightarrow \mathrm{T}_{2 \mathrm{~g}}$ transitions, respectively. ${ }^{30}$ The sharp a signal at 370 (for 1 ), and $377 \mathrm{~nm}$ (for 2) can be assigned to be charge transfer transition. Two bands at 284 and $225 \mathrm{~nm}$ (for $\mathbf{1}$ ) and 284 and $226 \mathrm{~nm}$ (for 2) assigned to intraligand $\pi-\pi^{*}$ transitions.

\section{2. Description of X-Ray Crystal Structures}

\section{2. 1. Crystal Structures of 1 and 2}

The molecular structure of nickel(II) complexes 1 and $\mathbf{2}$ are shown in Figs. 1 and 2, respectively. The com-

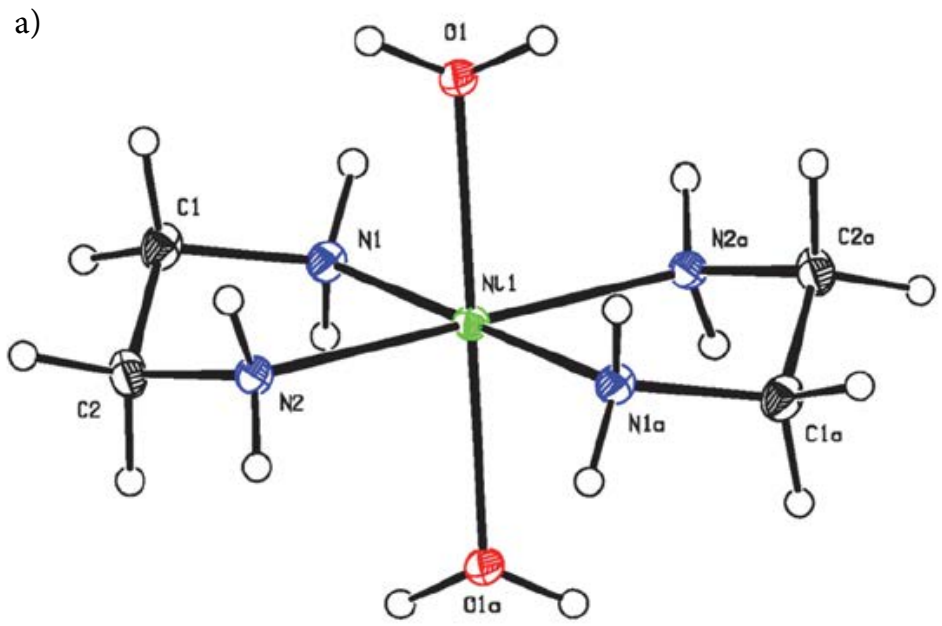

b)

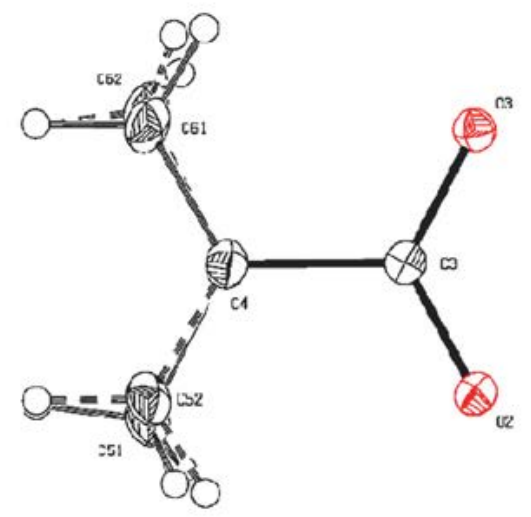

Fig. 1. The ORTEP view of complex 1 (a) with one methacrylate anion (b), showing $30 \%$ probability thermal ellipsoids

Vafazadeh et al.: Synthesis, X-ray Structural Characterization, ... 


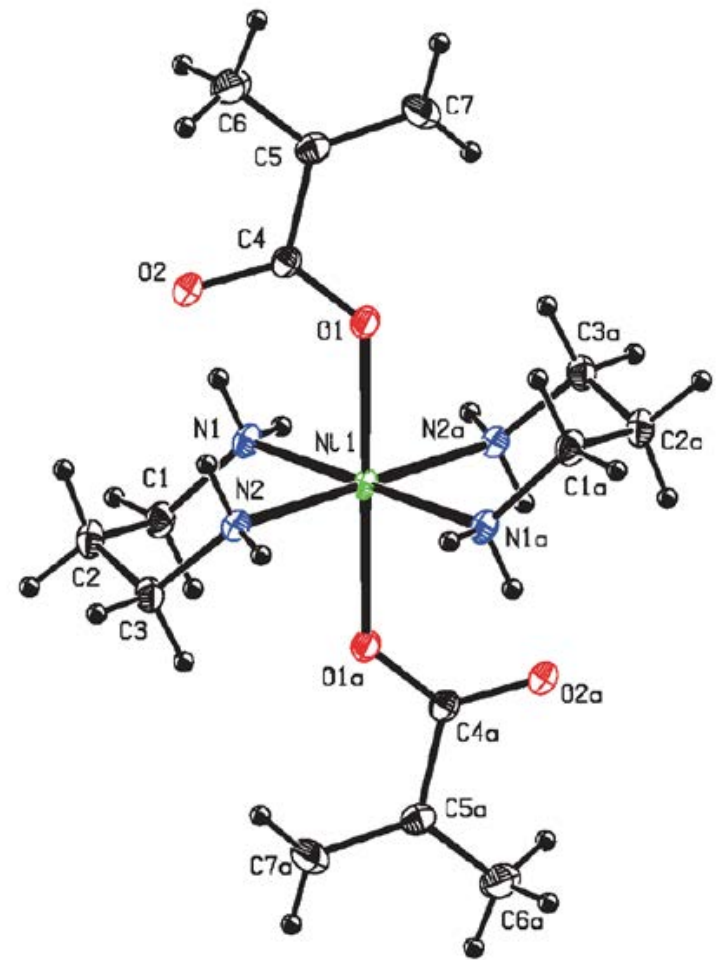

Fig. 2. The ORTEP view of complex 2 showing $30 \%$ probability thermal ellipsoids

plexes 1 and 2 crystallizes in monoclinic space group $C 2 / c$ and monoclinic space group $P 2 / c$ and there are four $(\mathrm{Z}=$ $4)$ and two $(Z=2)$ molecules in the unit cell, respectively.

The Ni-O and $\mathrm{Ni}-\mathrm{N}$ bond lengths of the complexes 1 and 2 have good agreement with $\mathrm{Ni}(\mathrm{II})$ complexes previously reported. ${ }^{31-33}$

In both complexes, the nickel(II) ion is six-coordinate $\left(\mathrm{N}_{4} \mathrm{O}_{2}\right.$ donor atoms) and have a distorted octahedral geometry. The equatorial plane is formed by four nitrogen atoms from two diamine ligands (ethylendiamine, $\mathbf{1}$, and 1,3-propylendiamine, 2) coordinates to the metal center. The ethylendiamine and 1,3-propylendiamine ligands form with $\mathrm{Ni}(\mathrm{II})$ atom five-membered and six-membered
Table 2. Selected bond lengths $(\AA)$ and angles $\left(^{\circ}\right)$ in complexes 1 and 2

\begin{tabular}{|c|c|c|c|}
\hline \multicolumn{2}{|c|}{ Bond lengths (Å) } & \multicolumn{2}{|c|}{ Bond angles $\left({ }^{\circ}\right)$} \\
\hline \multicolumn{4}{|c|}{ Complex 1} \\
\hline Ni1-N1 & $2.088(3)$ & N1-Ni1-N2 & $83.51(13)$ \\
\hline Ni1-N2 & $2.099(3)$ & $\mathrm{O} 1-\mathrm{Ni1}-\mathrm{O} 1^{\mathrm{a}}$ & 180 \\
\hline $\mathrm{Ni1}-\mathrm{O} 1$ & $2.159(3)$ & $\mathrm{N} 1-\mathrm{Ni} 1-\mathrm{N} 2^{\mathrm{a}}$ & $96.49(13)$ \\
\hline $\mathrm{C} 3-\mathrm{O} 2$ & $1.261(5)$ & N1-Ni1-O1 & $88.17(12)$ \\
\hline $\mathrm{C} 3-\mathrm{O} 3$ & $1.264(5)$ & $\mathrm{O} 3-\mathrm{C} 3-\mathrm{O} 2$ & $124.1(3)$ \\
\hline \multicolumn{4}{|c|}{ Complex 2} \\
\hline $\mathrm{Ni1-N1}$ & $2.105(2)$ & N1-Ni1-N2 & $86.69(9)$ \\
\hline Ni1-N2 & $2.104(2)$ & $\mathrm{O} 1-\mathrm{Ni1}-\mathrm{O} 1^{\mathrm{b}}$ & 180 \\
\hline $\mathrm{Ni1}-\mathrm{O} 1$ & $2.1225(19)$ & $\mathrm{N} 1-\mathrm{Ni} 1-\mathrm{N} 2^{\mathrm{b}}$ & $93.31(9)$ \\
\hline $\mathrm{C} 4-\mathrm{O} 1$ & $1.267(3)$ & N1-Ni1-O1 & $89.47(8)$ \\
\hline $\mathrm{C} 4-\mathrm{O} 2$ & $1.260(3)$ & $\mathrm{O} 1-\mathrm{C} 4-\mathrm{O} 2$ & $125.0(3)$ \\
\hline
\end{tabular}

chelate rings, respectively. The $\mathrm{Ni}-\mathrm{N}$ bond lengths in the complex 2 are at distances 2.104(2) and 2.105(2) $\AA$, which are longer than $\mathrm{Ni}-\mathrm{N}$ bond lengths (2.088(3) and 2.099(3) $\AA$ ) in the complex 1, possibly due to the increased chelate rings formed with the $\mathrm{Ni}(\mathrm{II})$ atom. The main difference between the two complexes is that in $\mathbf{1}$ where are two water molecules coordinated to the $\mathrm{Ni}$ (II) ion and two methacrylate ions are not coordinated to the $\mathrm{Ni}(\mathrm{II})$ ion and acts only as counter anions, whereas in $\mathbf{2}$ the two methacrylate ions are coordinated to the center ion. The $\mathrm{Ni}-\mathrm{O}$ bond length of complex $\mathbf{1}(2.159(3) \AA)$ is longer than the corresponding bond of complex 2 (2.1225(19) $\AA$ ). This variation is consistent with the anionic nature of the methacrylate ligands. The chelating $\mathrm{N}-\mathrm{Ni}-\mathrm{N}$ angle is $83.51(13)^{\circ}$ for 1 and $86.69(9)^{\circ}$ for 2 , whereas the non-chelating $\mathrm{N}-\mathrm{Ni}-\mathrm{N}$ angles are $96.49(13)^{\circ}$ and $93.31(9)^{\circ}$ for $\mathbf{1}$ and $\mathbf{2}$, respectively. Selected bond lengths and angles, as well as interatomic distances, are summarized in Table 2.

In $\mathbf{1}$, there is a disorder pattern in the packing of the $-\mathrm{C}\left(\mathrm{CH}_{3}\right)=\mathrm{CH}_{2}$ group over two positions, with relative occupancies of 52\%:48\% (Fig. 1b). However, in 2 two methacrylate ions are coordinated to the $\mathrm{Ni}(\mathrm{II})$ ion.

Table 3. Hydrogen bonding $(\AA)$ and angles $\left(^{\circ}\right)$ in complexes $\mathbf{1}$ and $\mathbf{2}$

\begin{tabular}{|c|c|c|c|c|c|c|}
\hline & $\mathbf{D}-\mathbf{H} \cdots A$ & D-H & $\mathbf{H} \cdots A$ & D $\cdots A$ & $\mathbf{D}-\mathbf{H} \cdots A$ & Symmetry code \\
\hline \multirow{7}{*}{1} & $\mathrm{~N} 1-\mathrm{H} 811 \cdots \mathrm{O} 1$ & $0.95(5)$ & $2.59(5)$ & $3.337(4)$ & $135(4)$ & $-x+3 / 2, y+1 / 2,-z+3 / 2$ \\
\hline & $\mathrm{N} 1-\mathrm{H} 811 \cdots \mathrm{O} 2$ & $0.95(5)$ & $2.44(5)$ & $3.214(4)$ & $139(4)$ & $x,-y+1, z+1 / 2$ \\
\hline & $\mathrm{N} 1-\mathrm{H} 812 \cdots \mathrm{O} 3$ & $0.91(5)$ & $2.15(5)$ & $3.041(4)$ & $170(4)$ & $x, y+1, z$ \\
\hline & $\mathrm{N} 2-\mathrm{H} 821 \cdots \mathrm{O} 3$ & $0.91(5)$ & $2.19(5)$ & $3.066(4)$ & $164(4)$ & $x,-y+1, z-1 / 2$ \\
\hline & $\mathrm{N} 2-\mathrm{H} 822 \cdots \mathrm{O} 2$ & $0.90(5)$ & $2.17(5)$ & $2.066(4)$ & $171(4)$ & $x, y, z$ \\
\hline & $\mathrm{O} 1-\mathrm{H} 911 \cdots \mathrm{O} 2$ & $0.96(5)$ & $1.78(5)$ & $2.731(4)$ & $172(4)$ & $-x+3 / 2,-y+1 / 2,-z+1$ \\
\hline & $\mathrm{O} 1-\mathrm{H} 912 \cdots \mathrm{O} 3$ & $0.84(6)$ & $1.91(6)$ & $2.747(4)$ & $173(4)$ & $x, y, z$ \\
\hline \multirow{4}{*}{2} & $\mathrm{~N} 1-\mathrm{H} 5 \cdots \mathrm{O} 2$ & $0.89(3)$ & $2.44(3)$ & $3.144(4)$ & $136(1)$ & $x, y, z$ \\
\hline & N2-H9...O2 & $0.88(3)$ & $2.16(3)$ & $3.007(4)$ & $162(1)$ & $-x+2, y-1 / 2,-z+1 / 2$ \\
\hline & $\mathrm{N} 1-\mathrm{H} 12 \cdots \mathrm{O} 2$ & $0.91(3)$ & $2.13(3)$ & $3.030(4)$ & $171(1)$ & $x,-y+3 / 2, z+1 / 2$ \\
\hline & $\mathrm{N} 2-\mathrm{H} 13 \cdots \mathrm{O} 2$ & $0.88(3)$ & $2.24(3)$ & $2.989(4)$ & $142(1)$ & $x, y, z$ \\
\hline
\end{tabular}


Crystal structures of complexes $\mathbf{1}$ and $\mathbf{2}$ both show hydrogen bonding interactions. In $\mathbf{1}$ one hydrogen atom of the coordinated water molecule is involved in a intramolecular hydrogen bonding interaction with the oxygen atom $\mathrm{O} 3$ of a methacrylate anion, and the other water $\mathrm{H}$ atom is hydrogen bonded to O2A of the methacrylate anion (symmetry code: $x,-y+1, z+1 / 2$ ), with donor(D)-acceptor(A) distances of 2.747(4) and 3.214(4) $\AA$ and $\mathrm{D}-\mathrm{H} \cdots \mathrm{A}$ angles of $173(5)$ and $139(4)^{\circ}$, respectively. Also, there is a hydrogen bonding interaction between the hydrogen atoms of the $\mathrm{NH}_{2}$ of the ethylendiamine ligands with the oxygen atoms of a methacrylate anion. In 2, there are hydrogen bonding interaction, between the hydrogen atoms bonded of the 1,3-propylendiamine with oxygen atoms of the methacrylate ligand. Full details of the hydrogen bonding are given in Table 3.

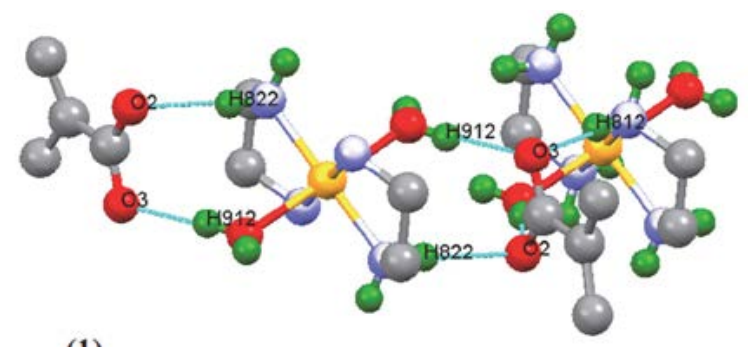

(1)

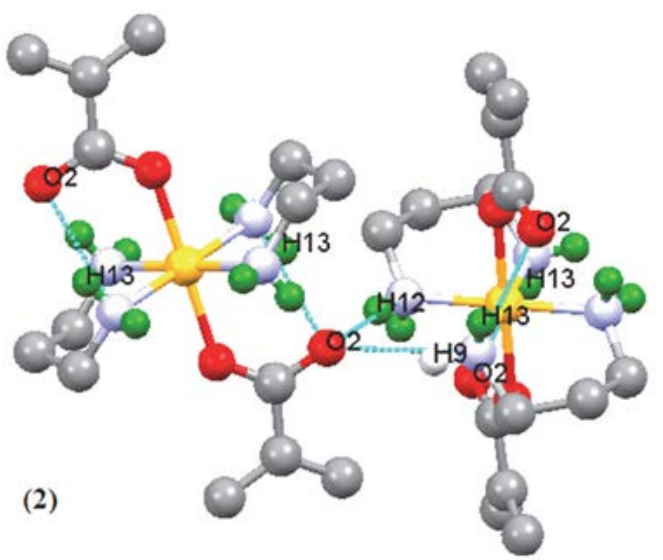

Fig. 3. Various hydrogen bonding interactions in complexes $\mathbf{1}$ and 2, other hydrogen atoms are omitted for clarity.

\section{3. DFT Optimized Geometries}

The geometry optimization of nickel(II) complexes was carried out in their singlet and triplet spin states. The optimized geometric parameters at their most stable spin states, which are triplet for complexes $\mathbf{1}$ and $\mathbf{2}$ is shown in Fig. 4.

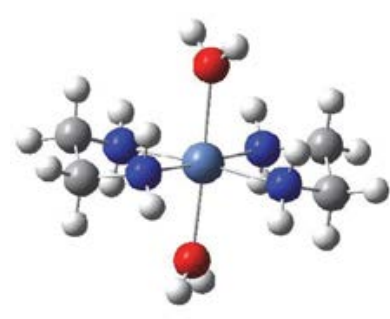

(1)

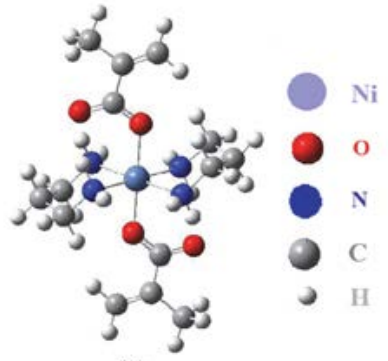

(2)
Fig. 4. The optimized structures of the complexes 1 and 2.

As shown in Table 4, the calculated bond lengths for the studied complexes agree well with the X-ray experimental data.

The differences between optimized geometrical parameters and experiment are less than $0.05 \AA$ (bond distances) and $2^{\circ}$ (bond angles) in most cases (Fig. 5).

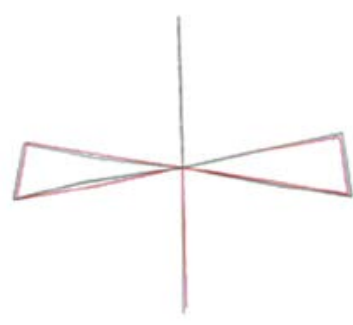

(1)

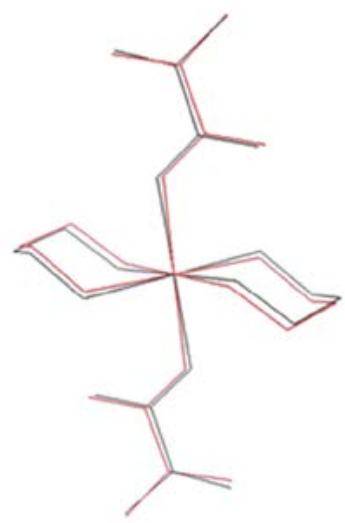

(2)
Fig. 5. Atom-by-atom superimposition of the calculated structures (black) over the X-ray structure (red); hydrogen atoms have been removed for clarity.

Table 4. Selected geometric parameters from X-ray experiment and DFT-B3LYP calculations

\begin{tabular}{llccccccc}
\hline Bond length $(\AA)$ & Expt. & Calc. & $|\boldsymbol{\Delta d}|$ & Bond angle $\left(^{\circ}\right)$ & Expt. & Calc. & $|\boldsymbol{\Delta \theta}|$ \\
\hline & Ni1-N1 & 2.09 & 2.10 & 0.01 & N1-Ni1-N2 & 83.5 & 82.11 & 1.4 \\
$\mathbf{1}$ & Ni1-N2 & 2.10 & 2.14 & 0.04 & O1-Ni1-O1 & 180 & 178.3 & 1.7 \\
& Ni1-O1 & 2.16 & 2.26 & 0.10 & N1-Ni1-O1 & 88.2 & 89.1 & 0.9 \\
\hline & Ni1-N1 & 2.10 & 2.16 & 0.06 & N1-Ni1-N2 & 86.7 & 83.6 & 3.1 \\
2 & Ni1-N2 & 2.10 & 2.16 & 0.06 & O1-Ni1-O1 & 180.0 & 180.0 & 0.0 \\
& Ni1-O1 & 2.12 & 2.10 & 0.02 & N1-Ni1-O1 & 89.5 & 89.8 & 0.3 \\
\hline
\end{tabular}

Symmetry codes: $a=-x+3 / 2,-y+3 / 2,-z+1 ; b=-x+2,-y+1,-z+1$ 
In general, the predicted bond lengths are slightly longer in comparison with the values based on the X-ray crystal structure data. The geometrical differences might be a result of crystal packing forces which have an influence on the molecules as expected for the experimental ones (solid state), but the calculated geometries are in the gas phase. ${ }^{34,35}$ The crystal packing forces, which have an influence on the molecules, as expected for the experimental parameters (solid state), is a reason for the difference of calculated bond lengths in the gas phase and solid phase.
The vibrational frequency calculations were performed based on the optimized structures of complexes. The calculated and experimental IR spectra of complexes are in good agreement with experimental data (Fig. 6 and Fig. S1).

The energies of the HOMO and LUMO molecular orbitals have been also calculated. The experimental values of HOMO-LUMO gap $(\Delta)$ for the complexes of $\mathbf{1}$ and $\mathbf{2}$ based on UV-Vis spectra are 5.51 and $5.49 \mathrm{eV}$, respectively, which corresponds to $n \rightarrow \pi^{*}$ transitions. The theoretical
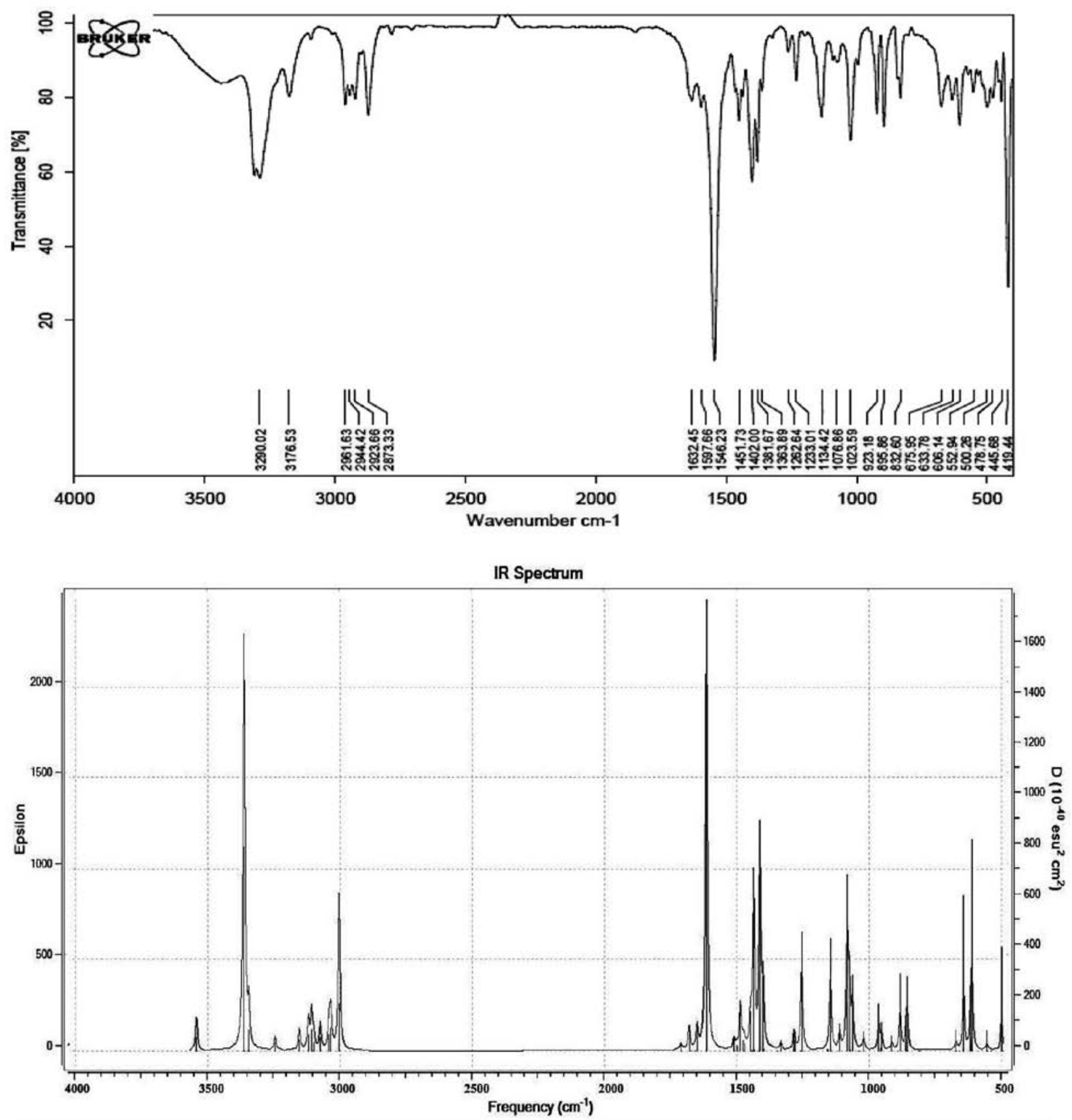

Fig. 6. The experimental (top) and calculated (down) IR spectra of complex 2. 
values have been calculated as 6.36 and $5.25 \mathrm{eV}$, respectively, which are in line with the experimental values with relatively low deviations.

The calculated charges on the metal centers in complexes 1 and 2 are +1.306 and +1.267 respectively, and these values are greatly lower than the formal charge of +2 . These differences are as a result of charge donation from the donor atoms of ligands.

\section{Conclusion}

The reaction of nickel(II) acetate with $\mathbf{L}^{1}$ and $\mathbf{L}^{2}$ ligands led to the formation of mononuclear complexes 1 and 2 . The crystal structures were determined for two studied complexes. In mononuclear nickel(II) complexes $\mathbf{1}$ and 2, metal centers are hexacoordinated with a distorted octahedral geometry. The optimized structure of the complexes has been studied using the B3LYP/6-31G(d)/LanL2DZ level of theory. The calculated molecular geometries are in a very good agreement with the experimental data. It has been revealed that the triplet state for nickel(II) complexes $\mathbf{1}$ and $\mathbf{2}$ are more stable than their singlet state.

\section{Supplementary Material}

The deposition numbers of the studied complexes, 1 and 2 are CCDC 1481553 and 1481554, respectively. These data can be obtained free-of-charge via www.ccdc.cam. ac.uk/data_request/cif, by emailing data-request@ccdc. cam.ac.uk, or by contacting The Cambridge Crystallographic Data Centre, 12 Union Road, Cambridge CB2 1EZ, UK; fax +44 1223336033 .

\section{Acknowledgement}

$\mathrm{MN}$ is thankful to Prof. Michelle L. Coote and Research School of Chemistry, The Australian National University for the offer of campus visiting position and for the Gaussian calculations. BS is grateful to the graduate school of Yazd University for the post-graduate scholarships. MN and RV are also grateful to Yazd University and the Australian National University for their valuable support.

\section{References}

1. G. C. Giri, A. Patra, G. Vijaykumar, L. Carrella, M. Bera, RSC Adv. 2015, 5, 99270-99283.

2. P. Bhowmik, S. Biswas, S. Chattopadhyay, C. Diaz, C. J. GómezGarcía, A. Ghosh, Dalton Trans. 2014, 43, 12414-12421

3. K. Zheng, L. Jiang, Y. T. Li, Z. Y. Wu, C. W. Yan, RSC Adv. 2015, 5, 51730-51744.
4. X. Sala, E. J. García Suárez, Z. Freixa, J. Benet-Buchholz, P. W. N. M. van Leeuwen, Eur. J. Org. Chem. 2008, 6197-6205.

5. H. Shirase, Y. Miura, Y. Fukuda, Monatsh Chem. 2009, 140, 807-814.

6. M. Behrens, S. Scherb, C. Näther, W. Bensch, Z. Anorg. Allg. Chem. 2003, 629, 1367-1373.

7. X. Wang, D. S. Yang, J. Phys. Chem. A 2006, 110, 7568-7576.

8. F. Emmenegger, C. W. Schlaepfer, H. Stoeckli-Evans, M. Piccand, H. Piekarski, Inorg. Chem. 2001, 40, 3884-3888.

9. H. Golchoubian, E. Rezaee, G. Bruno, H. Amiri Rudbari, Inorg.Chim. Acta, 2013, 394, 1-9.

10. L. N. Wang, L. Fu, J. W. Zhu, Y. Xu, M. Zhang, Q. You, P. Wang, J. Qin, Acta Chim. Slov. 2017, 64, 202-207.

11. C. J. Lina, J. L. Qia, Y. Q. Zheng, J. L. Lina, J. Coord. Chem. 2013, 66, 3877-3890.

12. R. Vafazadeh, Z. Moghadas, A. C. Willis, J. Coord. Chem. 2015, 68, 4255-4271.

13. G. T. Musie, X. Li, D. R. Powell, Inorg. Chim. Acta 2006, 359, 1989-1996.

14. S. Singh, D. Saini, S. K. Mehta, D. Choquesillo-Lazarte, J. Coord. Chem. 2011, 64, 1544-1553.

15. R. Vafazadeh, M. Namazian, M. Chavoshiyan, A. C. Willis, P. D. Carr, Acta Chim. Slov. 2017, 64, 613-620.

16. Agilent. CrysAlis PRO. Agilent Technologies Ltd, Yarnton, Oxfordshire, England, 2014.

17. A. Altomare, G. Cascarano, G. Giacovazzo, A. Guagliardi, M. C. Burla, G. Polidori, M. Camalli, J. Appl. Cryst. 1994, 27, 435-436.

18. P. W. Betteridge, J. R. Carruthers, R. I. Cooper, K. Prout, D. J. Watkin, J. Appl. Cryst. 2003, 36, 1487-1487.

19. W. J. Hehre, L. Radom, P. V. R. Schleyer, J. A. Pople, Ab initio Molecular Orbital Theory, Wiley, New York, 1986.

20. Gaussian 09, Revision D.01, M.J. Frisch, G. W. Trucks, H. B. Schlegel, G. E. Scuseria, M .A. Robb, J. R. Cheeseman, G. Scalmani, V. Barone, B. Mennucci, G. A. Petersson, H. Nakatsuji, M. Caricato, X. Li, H.P. Hratchian, A. F. Izmaylov, J. Bloino, G. Zheng, J. L. Sonnenberg, M. Hada, M. Ehara, K. Toyota, R. Fukuda, J. Hasegawa, M. Ishida, T. Nakajima, Y. Honda, O. Kitao, H. Nakai, T. Vreven, J.A. Montgomery Jr., J.E. Peralta, F. Ogliaro, M. Bearpark, J. J. Heyd, E. Brothers, K. N. Kudin, V. N. Staroverov, T. Keith, R. Kobayashi, J. Normand, K. Raghavachari, A. Rendell, J. C. Burant, S. S. Iyengar, J. Tomasi, M. Cossi, N. Rega, J. M. Millam, M. Klene, J .E. Knox, J. B. Cross, V. Bakken, C. Adamo, J. Jaramillo, R. Gomperts, R. E. Stratmann, O. Yazyev, A. J. Austin, R. Cammi, C. Pomelli, J. W. Ochterski, R. L. Martin, K. Morokuma, V. G. Zakrzewski, G. A. Voth, P. Salvador, J. J. Dannenberg, S. Dapprich, A. D. Daniels, O. Farkas, J. B. Foresman, J. V. Ortiz, J. Cioslowski, D. J. Fox, Gaussian Inc., Wallingford CT, 2010.

21. A. D. Becke, J. Chem. Phys. 1993, 98, 5648-5652.

22. L. A. Curtiss, P. C. Redfern, K. Raghavachari, J. Chem. Phys. 2007, 126, 084108-084120.

23. J. B. Foresman, A.E. Frisch, Exploring Chemistry with Electronic Structure Methods, Gaussian Inc., Pittsburgh, PA, 1998.

24. P. J. Hay, W. R. Wadt, J. Chem. Phys. 1985, 82, 270-283. 
25. P. J. Hay, W. R. Wadt, J. Chem. Phys. 1985, 82, 284-298.

26. P. J. Hay, W. R. Wadt, J. Chem. Phys. 1985, 82, 299-310.

27. J. P. Foster, F. Weinhold, J. Am. Chem. Soc. 1980, 102, 72117218.

28. Y. Thio, X. Yang, J. J. Vittal, Dalton Trans. 2014, 43, 3545- 3556.

29. K. Nakamoto, Infrared and Raman Spectra of Inorganic and Coordination Compounds, 4th ed., Wiley, New York, 1986.

30. B. Shaabani, A. A. Khandar, M. Dusek, M. Pojarova, F. Mahmoudi, A. Feher, M. Kajnakova, J. Coord. Chem. 2013, $66,748-762$.
31. R. Vafazadeh, A. Gorji, S. Ansari, A. C. Willis, Acta Chim. Slov. 2012, 59, 897-903.

32. P. Ghorai, A. Chakraborty, A. Panja, T. K. Mondal, A. Saha, RSC Adv. 2016, 6, 36020-36030.

33. D. Das, N. Sahu, S. Mondal, S. Roy, P. Dutta, S. Gupta, T. K. Mondal, C. Sinha, Polyhedron 2015, 99, 77-86.

34. R. Vafazadeh, B. Khaledi, A. C. Willis, M. Namazian, Polyhedron 2011, 30, 1815-1819.

35. G. Alpaslan, M. Macit, Spectrochim. Acta A 2014, 121, 372380.

\section{Povzetek}

Sintetizirali smo dva enojedrna $\mathrm{Ni}(\mathrm{II})$ kompleksa $\left[\mathrm{Ni}(\mathrm{en})_{2}\left(\mathrm{H}_{2} \mathrm{O}\right)_{2}\right](\mathrm{MAA})_{2}$ (1) in $\left.\mathrm{Ni}(\mathrm{pn})_{2}(\mathrm{MAA})_{2}\right]$ (2), kjer so MAA, en in pn metakrilat, etilendiamin in 1,3-propilendiamin. Okarakterizirali smo ju z elementno analizo, FT-IR in UVVis spektroskopijo. Strukture obeh kompleksov smo določili z monokristalno rentgensko analizo. V kompleksih 1 in $\mathbf{2}$ je okoli nikljevega(II) iona popačena oktaedrična geometrija. $\mathrm{Ni}(\mathrm{II})$ je v obeh spojinah vezan na štiri dušikove atome dveh diaminov ter nadalje na dva kisikova atoma aqua liganda v 1 oziroma dva kisikova atoma metakrilatnih ligandov v 2. Teoretične geometrije proučevanih spojin smo izračunali na podlagi teorije gostotnostnega funkcionala (DFT) na B3LYP/6-311+G(d,p)/LanL2DZ nivoju in ob uporabi efektivnih potencialov (ECP). Primerjava rezultatov kaže na dobro ujemanje uporabljene DFT metode $\mathrm{z}$ eksperimentalnimi podatki. 